\title{
Pain, health perception and sleep: impact on the quality of life of firefighters/rescue professionals ${ }^{1}$
}

\author{
Rafael Silva Marconato ${ }^{2}$ \\ Maria Ines Monteiro ${ }^{3}$
}

\begin{abstract}
Objective: to evaluate the quality of life of firefighters and rescue professionals, and characterize their socio-demographic, health, work and lifestyle profile. Methods: cross-sectional study that used a socio-demographic, lifestyle, health, work data questionnaire and the WHOQOL-BREF quality of life aspects, in Fire Department bases, Civil Air Patrol Group of the Military Police and Rescue Group of Emergency Services. Results: ninety professionals participated in this study 71 firefighters, 9 nurses, 7 doctors and 3 flight crew members. The average age of the group was $36.4 \pm 7.8$ years; they worked about 63.7 hours per week; $20.2 \%$ reported pain in the last week and $72.7 \%$ had body mass index above $25 \mathrm{~kg} / \mathrm{m} 2$. The average of the WHOQOL-BREF domains was: physical (74.6), psychological (75.2), social (76.5) and environmental (58.7). Significant association was found (Mann-Whitney test and Spearman correlation) between the WHOQOL-BREF domains and pain in the past six months, in the last week, health perception, job satisfaction, hours of sleep, domestic tasks and study. Conclusion: the main factors related to quality of life were presence of pain, health perception, sleep and domestic activity.
\end{abstract}

Descriptors: Work; Firefighters; Rescue Work; Quality of Life; Occupational Health; Nursing.

\footnotetext{
${ }^{1}$ Paper extracted from master's thesis "Firefighters and rescue professionals: work ability and quality of life", presented to Faculdade de Enfermagem, Universidade Estadual de Campinas, Campinas, SP, Brazil.

2 MSc, RN, Hospital das Clinicas, Universidade Estadual de Campinas, Campinas, SP, Brazil.

${ }^{3}$ PhD, Associate Professor, Faculdade de Enfermagem, Universidade Estadual de Campinas, Campinas, SP, Brazil.
}

Corresponding Author: Rafael Silva Marconato

Universidade Estadual de Campinas. Faculdade de Enfermagem

Rua Tessália Vieira de Camargo, 126

Cidade Universitária

CEP: 13083-887, Campinas, SP, Brasil

E-mail: marconato@hc.unicamp.br
Copyright (๑) 2015 Revista Latino-Americana de Enfermagem This is an Open Access article distributed under the terms of the Creative Commons Attribution Non-Commercial License (CC BY-NC).

This license lets others distribute, remix, tweak, and build upon your work non-commercially, and although their new works must also acknowledge you and be non-commercial, they don't have to license their derivative works on the same terms. 


\section{Introduction}

Some professions, especially firefighters and rescue professionals, deserve special attention regarding health care, since they are exposed to extreme demands on the physical, mental and social spheres in their daily work and, therefore, are susceptible to different health risks ${ }^{(1)}$.

The need to include health professionals, especially nurses and physicians, in the rescue system and outof-hospital salvations, led to the creation of the Rescue Group and Attention to Urgencies and Emergencies (GRAU) by the Ministry of Health of the State of São Paulo, consolidated by Decree No. 58,931, 2013, which currently has approximately 80 professionals, including doctors and nurses, and five operational bases, four located in São Paulo and one in Campinas ${ }^{(2)}$.

The professionals of Pre-Hospital Care (PHC) live expecting the emergency, which can generate fear of the unknown, emotional involvement, contact with the population and death. Therefore, they must be seen through a different perspective regarding working conditions, due to different everyday situations in an external and unprotected environment. The occupational risks become higher when related to flight for those who perform such transportation (3).

Firefighters are exposed to stress and physical demands at work, both can cause psychological damage related to the psychic, social and professional life ${ }^{(4)}$. Rescue workers, such as firefighters, nurses, doctors and drivers have high incidence of stress, sleepiness and fatigue, despite being a not very studied activity ${ }^{(5)}$.
The World Health Organization (WHO) defines quality of life as the individual's assessment of their position in life in the scope of culture and values, considering their goals, expectations, standards and concerns $^{(6)}$.

The objective of the study was to evaluate the quality of life of firefighters and rescue professionals and characterize their socio-demographic, health conditions, work and lifestyle profile.

\section{Method}

Cross-sectional and descriptive study, whose data were obtained through the quality of life instrument WHOQOL$\mathrm{BREF}^{(6)}$ and Socio-demographic Data questionnaire, Lifestyle, Health and Work Aspects (QSETS) ${ }^{(7)}$.

Data collection occurred from August to October 2013, in Campinas, state of São Paulo, Brazil, in the six Fire Department bases; a base of the Civil Air Patrol Group of the Military Police (Águia Group) and Rescue Group for Urgent Calls (GRAU).

The studied population covered the military firefighters, workers of the Águia Group, and nurses and doctors from GRAU, in a total of 134 professionals who perform direct service to users. Of these, 110 were firefighters, ten from the air rescue services (four nurses, six flight crew members) and 14 from GRAU (seven doctors and seven nurses). Individuals who were not in labor activity during the data collection period and firefighters of the administrative sector were excluded.

The final sample was composed of 90 individuals with response rate of $72.6 \%$ (Table 1 ).

Table 1 - Distribution of the study sample and response rate. Campinas, state of São Paulo, Brazil, 2014

\begin{tabular}{lccccc}
\hline \multicolumn{1}{c}{ Groups } & Assets & Eligible & Respondents & $\%$ & Categories \\
\hline Firefighters & 110 & 102 & 71 & 69.6 & 71 firefighters \\
GRAU & 14 & 14 & 14 & 100.0 & 7 doctors and 7 nurses \\
ÁGUIA & 10 & 08 & 05 & 92.5 & 2 nurses and 3 flight crew members \\
Total & 134 & 124 & 90 & 72.6 & \\
\hline
\end{tabular}

In the bases, one of the researchers introduced himself to the team, previously informed by their superior, who authorized the collection of data, inviting the professionals who voluntarily wanted to participate. They received a Free and Informed Consent Form, and the questionnaires were collected by the researcher.

After collection, the data were sorted and tabulated in Microsoft Exce ${ }^{\circledR}$ and exported to the SAS ${ }^{\circledR}$ statistical software (version 9.2), for descriptive and statistical analysis, with significance level lower than 5\%. For the correlations between quantitative variables we applied the Spearman correlation coefficient; for comparisons between the categorical variables, the Mann-Whitney test, and for the internal consistency of the WHOQOLBREF domains, the Cronbach's alpha coefficient.

This research respected the Resolution 196/96 and was approved under CAAE 13727813.5.0000.5404 by the Research Ethics Committee, via Plataforma Brazil. 


\section{Results}

Of the participating professionals, 48 (54.5\%) resided in Campinas or in its metropolitan region, 19 $(21.6 \%)$ in São Paulo, and $21(23.8 \%)$ in other cities; most of them (67-74.4\%) were married or lived with a partner. The salary range of $55.6 \%$ of the respondents (50) varied between $R \$ 1,555.00$ and $R \$ 3,172.00 ; 26$ employees $(28.8 \%)$ reported to be in the range between $\mathrm{R} \$ 3,172.00$ and $\mathrm{R} \$ 4,851.00$; and $15.6 \%$ (14) above this value.

Data concerning socio-demographic, work, lifestyle and health conditions characteristics are described in Table 2.

Table 2 - Distribution of absolute and relative frequencies of the variables socio-demographic, work, lifestyle and health conditions $(n=90)$. Campinas, state of São Paulo, Brazil, 2014

\begin{tabular}{|c|c|c|}
\hline Variables & $\mathbf{n}$ & $\%$ \\
\hline \multicolumn{3}{|l|}{ Age (years) } \\
\hline 20 to 29 & 19 & 21.3 \\
\hline 30 to 39 & 39 & 40.8 \\
\hline 40 to 49 & 25 & 28.0 \\
\hline 50 to 60 & 06 & 6.7 \\
\hline No information & 01 & \\
\hline \multicolumn{3}{|l|}{ Sex } \\
\hline Female & 03 & 3.3 \\
\hline Male & 87 & 96.7 \\
\hline \multicolumn{3}{|l|}{ Level of Education } \\
\hline High school/undergraduate & 51 & 58.0 \\
\hline Graduated from college/graduate & 37 & 42.1 \\
\hline No information & 02 & \\
\hline \multicolumn{3}{|c|}{ Perception of health status compared to people of the same age } \\
\hline Worse/a little worse & 3 & 3.3 \\
\hline Equal & 14 & 15.6 \\
\hline Better & 50 & 55.6 \\
\hline Much better & 23 & 25.6 \\
\hline \multicolumn{3}{|l|}{ Currently studying } \\
\hline No & 75 & 83.3 \\
\hline Yes & 15 & 16.7 \\
\hline \multicolumn{3}{|l|}{ Report of pain over the last six months } \\
\hline No & 62 & 68.9 \\
\hline Yes & 28 & 31.1 \\
\hline \multicolumn{3}{|l|}{ Report of pain in the last week } \\
\hline No & 71 & 79.8 \\
\hline Yes & 18 & 20.2 \\
\hline No information & 01 & \\
\hline \multicolumn{3}{|l|}{ Has another job } \\
\hline No & 63 & 71.6 \\
\hline Yes & 25 & 28.4 \\
\hline No information & 02 & \\
\hline
\end{tabular}

Table 2 - (continuation)

\begin{tabular}{lcc}
\hline \multicolumn{1}{c}{ Variables } & $\mathbf{n}$ & $\%$ \\
\hline Time spent to get to work and back home & & \\
Less than or equal to 2 hours & 64 & 71.9 \\
More than 2 hours & 25 & 28.1 \\
No information & 01 & \\
Job satisfaction & & \\
Dissatisfied/a bit unsatisfied/indifferent & 19 & 21.6 \\
Satisfied/very satisfied & 69 & 78.4 \\
No information & 02 & \\
Sleep well on working days & & \\
No & 16 & 17.8 \\
Yes & 74 & 82.2 \\
Sleep well on days off & & \\
No & 11 & 12.2 \\
Yes & 79 & 87.8 \\
Smokes & & \\
No & 88 & 97.8 \\
Yes & 02 & 2.2 \\
Ingests alcohol & & \\
No & 48 & 54.5 \\
Yes & 40 & 45.5 \\
No information & 02 & \\
Body mass index & & \\
Lower than 25 & 24 & 27.3 \\
Between 25 and 30 & 53 & 60.2 \\
Over 30 & 11 & 12.5 \\
No information & 02 & \\
\hline
\end{tabular}

It should be noted that religious belief was mentioned by $90 \%$ of the participants $(81), 72(80.9 \%)$ performed domestic activities and $91.1 \%$ (72) physical activity, $62.5 \%$ (45) for more than 210 minutes per week. The medium Body Mass Index (BMI) was $26.3 \mathrm{~kg} / \mathrm{m}^{2}(\mathrm{SD} \pm 3.5)$.

Of those interviewed, 29 (32.2\%) reported working overtime. Thirty-two (35.6\%) have been unemployed. The average number of hours worked was 63.7 hours (SD \pm 13.2 ), minimum of 24 and maximum of 100 hours per week.

In Figure 1, we observed the distribution of general average by facets and WHOQOL-BREF domains, highlighting the facets of domains related to environment, such as access to health services, financial resources and physical environment.

The average scores related to the WHOQOL-BREF domains were: physical of 74.6 (SD \pm 13.1 ), median of 78.6, minimum and maximum of 35.7 and 92.9, respectively; psychological equal to 74.6 ( $\mathrm{SD} \pm 13.5)$, median of 79.2 , minimum and maximum of 41.7 and 100.0 ; social relations obtained were $76.5(S D \pm 15.7)$, median of 75.5 , minimum and maximum of 66.7 and 100.0; and environmental of 58.7 ( $S D \pm 12.4$ ), median of 59.4, minimum and maximum of 18.8 and 84.4. The domains obtained a Cronbach's alpha coefficient superior to 0.7 . 


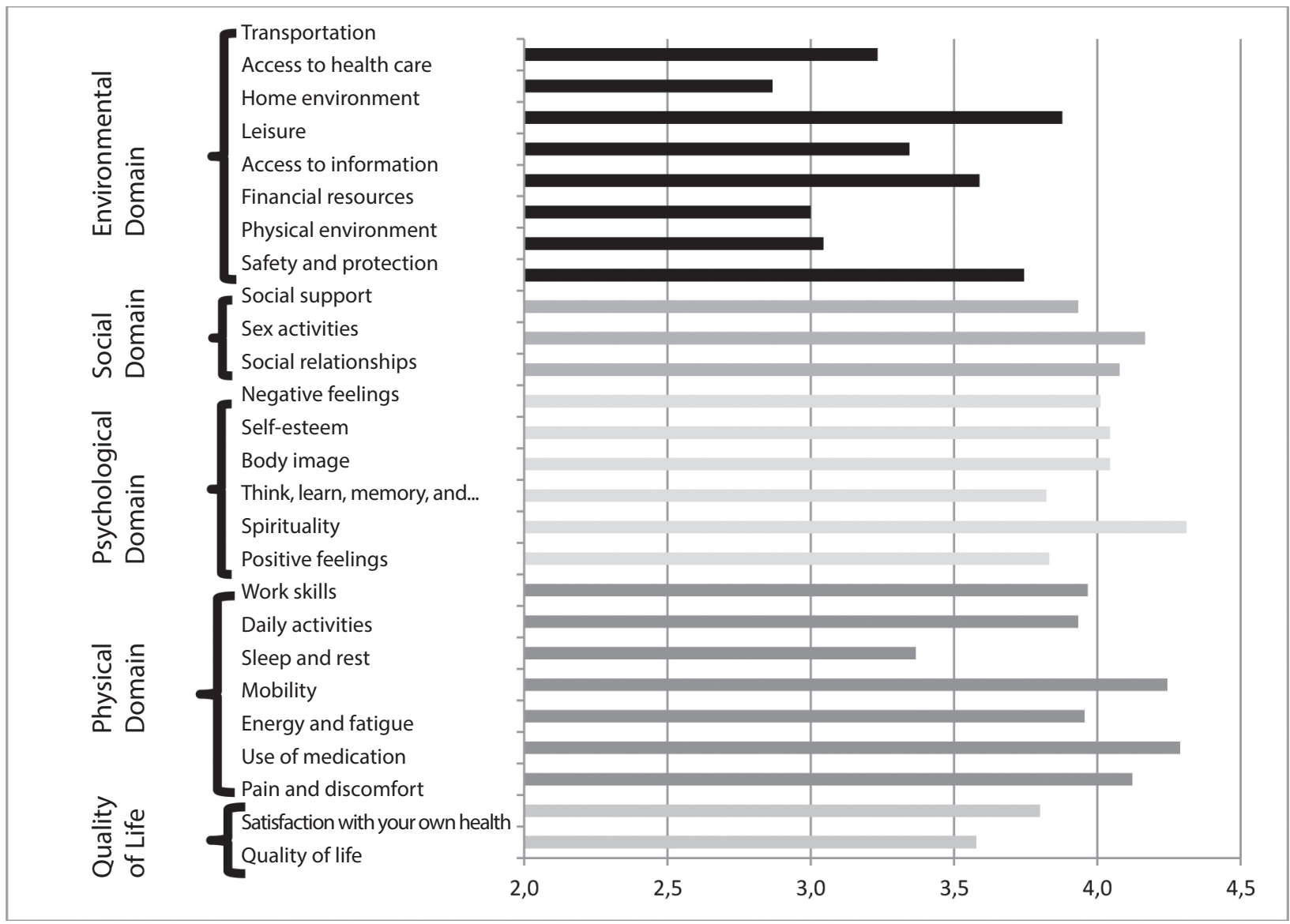

Figure 1 - Distribution of the WHOQOL averages by domains and facets, n=90. Campinas, state of São Paulo, Brazil, 2014

There was statistically significant association between the presence of pain in the last six months with the physical and environmental domains; presence of pain in the last week with the physical domain; perceptions of stress and health status when compared to people of the same age with all domains; job satisfaction with psychological and environmental domains; hours of sleep with the physical domain; to perform domestic tasks and study with the psychological domain (Tables 3 and 4).

Table 3 - Association of WHOQOL-BREF domains with the realization of household chores, current study, report of pain over the last six months and in the last week variables. Campinas, state of São Paulo, Brazil, 2014

\begin{tabular}{|c|c|c|c|c|c|c|c|c|c|c|}
\hline Domains & Variable & $\mathrm{n}$ & Average & $S^{*}$ & $\operatorname{Min}^{\dagger}$ & Q1\$ & Med"I & Q3" & $\operatorname{Max}^{\star *}$ & $p$-value ${ }^{t t}$ \\
\hline \multicolumn{11}{|l|}{ Psychological } \\
\hline & Household chores & & & & & & & & & 0.0315 \\
\hline & No & 17 & 81.1 & 7.5 & 70.8 & 70.8 & 83.3 & 87.5 & 91.7 & \\
\hline & Yes & 71 & 73.5 & 14.0 & 41.7 & 62.5 & 75.0 & 83.3 & 100.0 & \\
\hline & Currently studying & & & & & & & & & 0.0485 \\
\hline & No & 75 & 76.6 & 13.0 & 41.7 & 70.8 & 79.2 & 87.5 & 100.0 & \\
\hline & Yes & 14 & 68.2 & 14.2 & 45.8 & 58.3 & 68.8 & 79.2 & 87.5 & \\
\hline \multicolumn{11}{|l|}{ Physical } \\
\hline & Pain six months & & & & & & & & & $<0.0001$ \\
\hline & No & 62 & 79.0 & 8.9 & 57.1 & 71.4 & 80.4 & 85.7 & 92.9 & \\
\hline & Yes & 28 & 64.7 & 15,4 & 35.7 & 51.8 & 67.9 & 75.0 & 92.9 & \\
\hline & Pain week & & & & & & & & & $<0.0001$ \\
\hline & No & 71 & 78.4 & 10.0 & 50.0 & 71.4 & 82.1 & 85.7 & 92.9 & \\
\hline & Yes & 18 & 59.5 & 13.7 & 35.7 & 50.0 & 62.5 & 71.4 & 78.6 & \\
\hline
\end{tabular}


Table 3 - (continuation)

\begin{tabular}{|c|c|c|c|c|c|c|c|c|c|c|}
\hline Domains & Variable & $\mathrm{n}$ & Average & $S D^{*}$ & $\operatorname{Min}^{\dagger}$ & Q1§ & Med"I & Q3" & $\operatorname{Max}^{* *}$ & $p$-value ${ }^{t \dagger}$ \\
\hline \multirow[t]{3}{*}{ Environment } & & & & & & & & & & 0.0120 \\
\hline & No & 62 & 60.9 & 10.6 & 34.4 & 56.3 & 62.5 & 65.6 & 84.4 & \\
\hline & Yes & 28 & 53.9 & 14.9 & 18.8 & 45.3 & 56.3 & 60.9 & 84.4 & \\
\hline
\end{tabular}

*Standard Deviation

†Minimum

‡1st Quartile

I|Median

ๆ3rd Quartile

**Maximum

†+Mann-Whitney Test

Table 4 - Association between the WHOQOL-BREF domains and lifestyle variables. Campinas, state of São Paulo, Brazil, 2014

\begin{tabular}{|c|c|c|c|}
\hline Domain & & Hours of sleep per day & $\begin{array}{l}\text { Perception of health status compared to people of } \\
\text { the same age }\end{array}$ \\
\hline \multirow[t]{3}{*}{ Physical } & Spearman Coefficient* & 0.3030 & 0.3521 \\
\hline & p-value & 0.0043 & 0.0007 \\
\hline & $\mathrm{n}$ & 87 & 90 \\
\hline \multirow[t]{3}{*}{ Psychological } & Spearman Coefficient* & 0.1001 & 0.3637 \\
\hline & $p$-value & 0.3591 & 0.0005 \\
\hline & $\mathrm{n}$ & 86 & 89 \\
\hline \multirow[t]{3}{*}{ Social } & Spearman Coefficient* & 0.0214 & 0.3373 \\
\hline & $p$-value & 0.8442 & 0.0012 \\
\hline & $\mathrm{n}$ & 87 & 90 \\
\hline \multirow[t]{3}{*}{ Environment } & Spearman Coefficient* & 0.1933 & 0.2990 \\
\hline & p-value & 0.0729 & 0.0042 \\
\hline & $\mathrm{n}$ & 87 & 90 \\
\hline
\end{tabular}

*Spearman's rank correlation coefficient

\section{Discussion}

The method to enter the military career occurs through contest, the allocation is random and depends on the position's availability. On the other hand, the 24hour shift and 48 of rest favors the maintenance of the link by facilitating time of coming and going from work. WHO considers satisfaction with means of transport one of the facets to measure quality of life $^{(6)}$. The results showed that $28 \%$ of respondents reported needing more than two hours to get to work, however, the statistical tests did not identify relation between transportation time and quality of life scores.

We observed that the average of worked hours per week in the sample is high (63.7 hours). The workload is an important predictor of health(3), but, for this study, this association was not significant.

The large amount of time spent going and coming from work can interfere with the quality of life, especially when combined with the heavy workload of these professionals, especially firefighters, needs to be better planned to reduce exposure to occupational hazards.
In this survey, the majority (96.8\%) of respondents were male, justified by the fact that women were only admitted in the Firefighters Corporation of the state of São Paulo in the $1990 s^{(8)}$. It also reflects the difficulty that women still face to enter in a predominantly male universe. This reality is not just Brazilian, a North American study ${ }^{(9)}$ discusses this difficulty and, despite Governmental and social incentives, just $3.7 \%$ of firefighters are women.

More than $50 \%$ of the respondents were older than 36 years. With the population's aging, the trajectory of life perspective must be adopted, with attention to determinants that interfere in active aging(10). Only six participants $(6.7 \%)$ were older than 50 years, showing that this profession and its requirements need to be better assessed to chart strategies that enable more time to these professionals in the working life. These data corroborate a research from Finland, in which the average age of firefighters was 35.7 years oscillating between 22 and 49 years $^{(1)}$.

Most received between $\mathrm{R} \$ 1,555.00$ and $\mathrm{R} \$ 3,172.00$, a salary range above the national average 
of $\mathrm{R} \$ 1,110.71^{(11)}$. We must emphasize that more than $42.1 \%$ of the participants had a college degree, what makes this average wage low and compromises the quality of life. The financial resources facet had one of the lowest averages in the environmental domain, as well as the lowest average (58.7) among the WHOQOLBREF domains.

From the sample, 90\% reported that they had a religious belief. Religiosity and spirituality have influence on firefighters' labor activities due to the exposure to frequent situations of stress, and efficiency in the recovery after the confrontation of these situations ${ }^{(12)}$.

We also found an unemployment history between $28.4 \%$ of the participants, with an average of 14.1 months, which can be one of the reasons why even with the heavy workload and exposure to risk situations, $78.4 \%$ of the respondents said they are satisfied or very satisfied with their work.

The firefighter profession requires physical fitness, and we identified physical activity as part of the daily life of this group, as $91.1 \%$ of participants reported to practice physical activity regularly and, of these, more than $62 \%$ for approximately 210 minutes of exercise per week. However, there was no significant difference in the association between the practice of physical activity and the WHOQOL-BREF domains. Another study, conducted with 625 American firefighters subjected to highintensity training showed that those who participated in the activity were two times more likely to achieve the physical activity recommendations when compared to those who did not participate(13).

Even with the high frequency of physical activity, the average BMI of the individuals was $26.23 \mathrm{~kg} / \mathrm{m}^{2}$, and over $50 \%$ of workers were overweight. A North American research(14) showed that being overweight increases significantly the chances to contract occupational disease, to suffer accidents at work or to need days off. That is why actions to lower the BMI of these workers must be considered to reduce occupational hazards inherent to the work. Obesity decreases the physical resistance of these professionals and increases the risk of back pain, aside from being a risk factor for many diseases, especially the cardiovascular and metabolic ones $^{(14)}$. We identified that this prevalence is higher, reaching $72.7 \%$ of the sample studied, when considered overweight and obesity. It stands out that, in that same group, $81.2 \%$ considered having the health status better or much better than other people of the same age, which suggests that obesity may not be considered a health problem for these workers.
Sleeping hours showed positive correlation with the physical WHOQOL-BREF domain $(p=0.0043)$. A Finnish study ${ }^{(15)}$ performed with firefighters also highlighted the relation between quality of life and sleep patterns.

Being pleased with the job showed correlation with two of the four WHOQOL-BREF domains: psychological $(p=0.0187)$ and environmental $(p=0.0065)$. When considering the question "do you consider your health to be better or much better than people of the same age", there was positive correlation with all of the WHOQOLBREF areas, demonstrating that the perception of well-being and positive feelings are directly related to quality of life.

Results show that at least $31.1 \%$ of the subjects complained about some kind of pain in their daily life and supports studies ${ }^{(3-16)}$, such as investigating the incidence of Work-related Musculoskeletal Disorders (WMSDs) in Korean firefighters, in which $11 \%$ of the subjects were suffering from pain, aside from the relation of stress in its development ${ }^{(16)}$. A Brazilian research, performed with pre-hospital service workers $^{(3)}$, identified that the presence of pain was related to decreased capacity for work and there was prevalence of pain in $56 \%$ of the participants, demonstrating that the emergency service can be an important factor in the development of this symptom.

Smoking is a risk factor for many diseases and the percentage of smokers in the state of São Paulo is decreasing(17). In this study, the prevalence of smoking was low (2.2\%). Another Brazilian study, conducted with firefighters in the state of Minas Gerais, has also identified low prevalence of smokers in the corporation $(7.7 \%)$ and linked smoking to low educational levels, intermediate range of monthly income, presence of psychiatric problems in the past, high exposure to traumatic events in life, social discrimination, operational stressors and low demand of work ${ }^{(18)}$.

Almost half of the individuals $(45.5 \%)$ reported to consume alcohol regularly. A study with New York firefighters, showed that approximately $58 \%$ of the subjects ingest alcohol often ${ }^{(19)}$. Furthermore, the use of alcoholic beverage is related to the worsening of insomnia and depression and the frequent consumption of alcohol was attributed, mainly, as a relief of the high mental and physical demands of the job and social acceptability(19).

Work-related accidents reached $11.3 \%$ of the participants and, although in this research statistical relationship with quality levels of life was not demonstrated, these accidents are related to 
the presence of pain, job satisfaction, among other conditions that can influence these rates. A French study with firefighters accompanied the work accidents that occurred with 309 workers from that location, a relation between the time of the day and the amount of accidents was identified, concentrated in the nighttime and in the early hours of the morning, even though the peak calls do not occur in these periods(20).

Scores of the four WHOQOL-BREF domains showed an average similar to a study developed in Croatia(21) with firefighters, given that the results obtained by domain in this research and the Croatian one were, respectively: physical $74.6 \%$ and $80.8 \%$; psychological $75.2 \%$ and $73.7 \%$; social relationship $76.5 \%$ and $75.9 \%$ and, finally, the environmental domain presented difference because, in the research, the percentage was $58.7 \%$ compared to $70.8 \%$ of the international study. The environment domain includes aspects related to the country's structure, such as means of transport, security and access to health, therefore, this divergence may be due to differences in the regions studied.

In the physical domain, we highlight sleep and rest aspects with an average lower than the other and, in this study, at least $17 \%$ of workers reported having trouble to sleep. Problems with sleep were also identified in a research with pre-hospital service workers, conducted in the same region of this study ${ }^{(3)}$. A study with American firefighters identified that $37.2 \%$ had change in sleep and were more prone to cardiovascular disease, diabetes, depression and anxiety ${ }^{(22)}$.

In the psychological domain, two aspects drew attention due to low average scores: regarding the ability to think, concentrate and memory and on positive thoughts. The high average of the spirituality aspect called attention. An international study reported a relationship between positive thinking and spirituality and good quality of life(23). The spiritual link helped firefighters to overcome post-traumatic stress ${ }^{(12)}$. Therefore, the high score of this aspect is of extreme importance.

The relationship domain with the environment, which explores issues related to housing, security, freedom, financial resources, access to health services and transport conditions presented the lowest averages. The average regarding security and protection was 3.7 , value that that can be justified by the current public security crisis in the country. An international non-governmental organization, The Social Progress Imperative ${ }^{(24)}$, assessed the quality of life in various countries and, in 2014, it assessed the level of personal safety in 132 countries, ranking Brazil in the $122^{\text {nd }}$ position, what can justify the lack of security identified in the results of the sample studied. The lack of access to health services, transportation, leisure and information also stands out in this domain, all items directly related with the management of public services that require reflections and actions to improve the quality of life levels(24).

As limitation of the study, we point out the nonparticipation of professionals distant from work and administrative workers, which may represent a bias in the study.

\section{Conclusion}

WHOQOL-BREF scores were high in the physical, psychological and social relation domains, the lowest score occurred in the environment domain. Aspects that stood out negatively were: sleep and rest, ability to perform everyday activities, have positive thoughts, ability to think, learn, memory and concentration, safety and protection, physical environment, financial resources, access to information, access to leisure, home environment, access to health care and transportation.

Variables that showed statistical relationship with the WHOQOL-BREF domains were: health perception compared to people of the same age, hours of sleep, be satisfied with the work, be studying and performing domestic activity.

We emphasize that the creation of this group of doctors and nurses (GRAU) shows important perspective of growth in the number of nursing professionals that perform their function under conditions similar to these professionals.

Nursing professionals are part of the multidisciplinary team that can act to intervene in the risk factors workers are exposed, to reduce the harms to health. It is important to meet this group of workers, with workload above the national average, who coexists with pain, report problems with sleep and whose work performance is interfering with their quality of life.

We expect that the data collected in this study will serve as a base for other researchers to investigate the specific characteristics of these professionals, and to be used by the fire service managers to help them discuss their routines and possibilities to improve their living and working conditions and, finally, to assist public policymakers in decision-making. 


\section{References}

1. Airila A, Hakanen JJ, Luukkonen R, Lusa S, Punakallio A. Positive and negative mood trajectories and their relationship with work ability, self-rated health, and life satisfaction: a 13-year follow-up study. J Occup Environ Med. 2013;55(7):779-85.

2. Machado CV, Salvador FGF, O'DwyerI G. Serviço de atendimento móvel de urgência: análise da política brasileira. Rev Saúde Pública. 2011;45(3):519-28.

3. Vegian CF, Monteiro MI. Living and working conditions of the professionals of the a Mobile Emergency Service Rev. Latino-Am. Enfermagem. 2011;19(4):1018-24.

4. Vitari FC, Francisco HS, Mello MGS. Ergonomic risks on the operational activities of firefighters from Rio de Janeiro. Work. 2012;41:5810-2.

5. Patterson PD, Suffoletto BP, Kupas DF, Weaver MD, Hostler D. Sleep quality and fatigue among pre hospital providers. Pre Hosp Emerg Care. 2010;14(2):187-93.

6. Fleck, MPA, Louzada S, Xavier M, Chachamovich E, Vieira G, Santos E, et al. Aplicação da versão em português do instrumento abreviado de avaliação de qualidade de vida WHOQOL-BREF. Rev Saúde Pública. 2000;34(2):178-83.

7. Monteiro MI. Questionário de dados sociodemográficos, estilo de vida e aspectos da saúde e trabalho- QSETS. Campinas, Grupo de Estudos e Pesquisas em Saúde e Trabalho; 1996.

8. Polícia Militar do Estado de São Paulo (BR). Corpo de bombeiros. [Internet]. [Acesso 11 abr 2014]. Disponível em: http://www.corpodebombeiros.sp.gov.br/

9. Jahnke SA, Poston WSC, Haddock CK, Jitnarin N, Hyder ML, Horvath $C$. The health of women in the US fire service. BMC Womens Health. [Internet]. 2012. [Acesso 5 mai 2014]; 12(39):39. Disponível em: http://www. biomedcentral.com/1472-6874/12/39

10. Kalache A. Coping with the longevity revolution. Cienc Saúde Coletiva. 2014;19(8):3306.

11. Chadad JPZ, Pozzo RG. Mercado de trabalho no Brasil na primeira década do século XXI: evolução, mudanças e perspectivas - desemprego, salários e produtividade do trabalho. São Paulo: FIPE; 2013. 19 p. Dísponivel em http://www.fipe.org.br/publicacoes/downloads/ bif/2013/5_13-32-chahad-pozzo.pdf

12. Ogińska-Bulik N. Negative and positive effects of traumatic experiences in a group of emergency service workers: the role of personal and social resources. Med Pr. 2013;64(4):463-72.

13. Jahnke SA, Hyder ML, Haddock CK, Jitnarin N, Day RS, Poston WS. High-intensity fitness training among a national sample of male career firefighters. Saf Health Work. 2015;6(1):71-4.

14. Jahnke SA, Poston WSC, Haddock CK, Jitnarin N. Obesity and incident injury among career firefighters in the central United States. Obesity. 2013;21(8):1505-8. 15. Airila A; Hakanen J, Punakallio A, Lusa S, Luukkonen $R$. Is work engagement related to work ability beyond working conditions and lifestyle factors? Int Arch Occup Environ Health. 2012;85(1):915-25.

16. Kim MG, Kim KS, Ryoo JH, Yoo SW. Relationship between occupational stress and work-related musculoskeletal disorders in Korean male firefighters. Ann Occup Environ Med. [Internet] 2013. [Acesso $1 \mathrm{abr}$ 2014]; 25:9. Disponível em: http://www.aoemj.com/ content/25/1/9

17. Ministério da Saúde. Vigilância de fatores de risco e proteção para doenças crônicas por inquérito telefônico (Vigitel Brasil). Brasília: Ministério da Saúde; 2013. 135 p. Disponível em: https://biavati.files.wordpress. com/2014/05/vigitel-2013.pdf

18. Lima EP, Assunção AA, Barreto SM. Tabagismo e estressores ocupacionais em bombeiros, 2011. Rev Saúde Pública. 2013;47(5):897-904.

19. Carey MG, Al-Zaiti SS, Dean GE, Sessanna L, Finnell DS. Sleep problems, depression, substance use, social bonding and quality of life in professional firefighters. J Occup Environ Med. 2011;53(8):928-33.

20. Riedel M, Berrez S, Pelisse D, Brousse E, Forget C, Marlot $M$, et al. 24-hour pattern of work- related injury risk of French firemen: nocturnal peak time. Chronobiol Int. 2011 Oct;28(8):697-705.

21. Sorić $M$, Golubić $R$, Milosević $M$, Juras $K$, Mustajbegović J. Shift work, quality of life and work ability among Croatian hospital nurses. Coll Antropol. 2013;37(2):379-84.

22. Barger LK, Rajaratnam SM, Wang W, O'Brien CS, Sullivan JP, Quadri S, et al. Common sleep disorders increase risk of motor vehicle crashes and adverse health outcomes in firefighters. J Clin Sleep Med. 2015;11(3):233-40.

23. Airila A, Hakanen JJ, Luukkonen R, Lusa S, Punakallio A. Positive and negative mood trajectories and their relationship with work ability, self-rated health, and life 
satisfaction: a 13-year follow-up study. J Occup Environ

Med. 2013;55(7):779-85.

24. The Social Progress Imperative. Social progress index 2014. [Internet]. [Acesso 10 mai 2014]. Disponível em: http://www.socialprogressimperative.org/data/spi. 